\title{
Egészségfejlesztő program középiskolások körében - Az alapállapot felmérés eredményei
}

\author{
Health promoting programme among high school students - \\ The result of the baseline survey
}

Szerzők: Pénzes Gabriella $\bowtie$, Bíró Éva

Debreceni Egyetem, Népegészségügyi Kar, Megelőző Orvostani Intézet, Egészségfejlesztési tanszék

Beküldve: 2018. 05. 07.

doi: 10.24365/ef.v59i4.291

\begin{abstract}
Bevezetés: Napjainkban a legfőbb haláloki tényezők közé tartoznak a daganatos valamint a szívés érrendszeri betegségek, mely kórokok kialakulásához az egészségtelen életmód nagyban hozzájárul. A betegségteher csökkentése és e betegségek megelőzése érdekében fontos, hogy már fiatalkorban megtörténjen az egészséges életmód rutinjának elsajátítása, melyre a család mellett az iskola gyakorolja a legnagyobb hatást. Ezért célul tűztük ki egy egészséges életmód elsajátítását célzó egészségfejlesztő program kidolgozását középiskolások körében, mely folyamat első lépése a jelen közlemény keretei között bemutatott alapállapot-felmérés az egészségmagatartás, egészségi állapot és egészséges életmóddal kapcsolatos tudás vonatkozásában.
\end{abstract}

Módszertan: Vizsgálati populációnkat egy Hajdú-Bihar megyei középiskola 9. évfolyamos diákjai alkotják, akik körében 2016 őszén került sor az alapállapot felmérésre. Az adatfelvételünk magvát egy önkitöltős, egészségmagatartásra és egészségi állapotra vonatkozó kérdéseket tartalmazó kérdőiv, egy egészséges életmóddal kapcsolatos tudásteszt, és egy tápláltsági állapot mérés adta. Az adatelemzés során megvizsgáltuk, hogy oktatási intézménytípusonként van e különbség a tanulók egészségi állapotában és egészségmagatartásában, melyhez khi-négyzet próbát, Fisher-egzakt tesztet, ANOVA-t, illetve a nem normál eloszlású folytonos változók esetén Kruskal-Wallis tesztet alkalmaztunk.

Eredmények: A felmérésben 130 tanuló vett részt, mely tanulók 33,9\%-a gimnáziumi, 36,9\%-a szakgimnáziumi, 29,2\%-a pedig szakközépiskolai osztályba járt. Felmérésünkből kiderült, hogy a különböző oktatási intézménytípusban tanulók egészségmagatartása és egészséges életmóddal kapcsolatos tudása eltér. A szakközépiskolába járók több édességet $(p=0,034)$ és üdítőitalt $(p=0,001)$ fogyasztottak, inaktívabbnak mutatkoztak társaiknál $(p=0,001)$. A gimnazisták kevesebb időt töltöttek hétvégenként számítógép vagy más elektronikus eszköz (táblagép, okostelefon) használatával $(p=0,013)$, körükben alacsonyabb volt a rendszeresen dohányzók aránya $(p<0,001)$, a részegség életprevalenciája $(p=0,009)$, és a szexuális kapcsolatot létesítettek aránya $(p=0,001)$, valamint a tudásteszten ők írták a legmagasabb átlagpontszámot $(p=0,011)$.

Következtetés: Ezen kezdeti eredmények az intervenció tervezéséhez és fejlesztéséhez adnak segítséget, ezek alapján kerülnek kiválasztásra a program során tárgyalt témák, a tanulók tudásában meglévő különbségeket pedig az egyes foglalkozások felépítése során vesszük figyelembe.

Kulcsszavak: egészségmagatartás, serdülők, egészségfejlesztő program 
Introduction: Nowadays the leading causes of death are cancers and cardiovascular diseases, which are determined mostly by unhealthy lifestyle. In order to reduce burden of diseases and prevent these diseases, it is important to get the routine of healthy lifestyle early in the juvenile, on which the school may have the greatest impact in addition to the family. Therefore, the aim of our research is the development of a health promoting program among high school students in order to help them to lead a healthy lifestyle. In this article the results of the baseline survey, as the first step of this process, will be presented.

Methodology: Our study population contain 9th grade students of a high school in Hajdú-Bihar county, the baseline survey was carried out during the autumn of 2016. Our survey consists of a self-administered health and behaviour questionnaire, a test aimed to measure the healthy lifestyle-related knowledge, and a nutritional status measurement. During the data analysis, the chisquare and Fisher exact test, ANOVA and in the case of the non-normal distributed continuous variables Kruskal-Wallis test were used in order to investigate the differences between the different types of institutions at the high school.

Results: 130 students participated in the study, from them 33.9\% were in high school, $36.9 \%$ in secondary school and $29.2 \%$ in vocational school. Our survey revealed that there is a difference between the behaviour and knowledge among students from different types of institutions. The students in vocational training consumed more sweets $(p=0.034)$ and soft drinks $(p=0.001)$, were more inactive than their counterparts $(p=0.001)$. The high school students spent the least time with computer use on weekends $(p=0.013)$, the proportion of regular smokers $(p<0.001)$, the lifetime prevalence of drunkenness $(p=0.009)$ and the proportion of those who already have sexual intercourse $(p=0.001)$ was the lowest, while they reached the highest average score on the knowledge test $(p=0.011)$.

Conclusions: These initial results help to plan and develop the program, since the topics of the program will be chosen based on them and the existing differences in the knowledge of the students will also take into consideration during the sessions.

Keywords: health behaviour, adolescents, health promoting programme

\section{BEVEZETÉS}

Napjainkban Magyarországon a korai halálozás legfőbb oki tényezői a daganatos megbetegedések és a keringési rendszer betegségei, melyek kialakulásához az egészségtelen táplálkozás, a mozgásszegény életmód, illetve a káros szokások nagyban hozzájárulnak. Ezen betegségek elkerülése végett fontos, hogy már fiatalkorban megtörténjen az egészséges életmód rutinjának elsajátítása. ${ }^{1}$

A fiatalok egészségmagatartásával kapcsolatban több kutatás is folyt és folyik, nemzetközileg és Magyarországon egyaránt. Az Iskoláskorú gyermekek egészségmagatartása (Health Behaviour in School-aged Children, HBSC) az Egészségügyi Világszervezettel együttműködésben zajló nemzetközi kutatás, melynek keretében az 5., 7., 9., és 11. évfolyamos tanulók egészségi állapotát és egészségmagatartási szokásait mérik fel 4 évente.
A legutolsó adatfelvétel a 2013-2014-es tanévben történt, melynek eredményeit 2016-ban publikálták, csak úgy, mint a nemzetközi HBSC beszámolót. E felmérés alapján elmondható, hogy a hazai iskoláskorúak táplálkozási és testmozgási szokásai nemzetközi viszonylatban nézve sem megfelelőek, valamint a rendszeresen dohányzók, alkoholt fogyasztók, lerészegedők és szexuálisan aktívak arányát tekintve vezető helyet foglalunk el a nemzetközi tabellán. ${ }^{2,3}$

A HBSC kutatáson kívül, a fiatalok rizikómagatartásaival az „Európai iskolavizsgálat a fiatalok alkoholés egyéb drogfogyasztási szokásairól” (European School Survey Project on Alcohol and other Drugs, ESPAD) kutatás is foglalkozik. Ennek az iskolavizsgálatnak a célja, hogy a fiatalok fogyasztási szokásairól 4 évenként ismétlődő, időben és nemzetközileg összehasonlítható adatokat gyűjtsön. Az utolsó jelentést 2016-ban publikálták, mely felmérést a 
16. életévüket a felmérés évében betöltők körében végezték. A 2014-es HBSC kutatás eredményeihez hasonlóan, az ESPAD vizsgálatban résztvevő országok átlagértékéhez képest a magyar fiatalok közül többen dohányoznak rendszeresen, és a problémás alkoholfogyasztás is gyakrabban jellemző rájuk. ${ }^{4,5}$

A nemzetközi vizsgálatokon túlmenően a 20142015-ös tanévben hazánkban megvalósított Iskolai Egészségkommunikációs Felmérés (iEKF) az 5., 7., és 9. osztályos tanulók életmódjáról és egészséggel kapcsolatos ismereteikről, attitűdjükről, valamint kommunikációs szokásaikról gyűjtött információt. A vizsgálatból kitűnik, hogy a fiatalok az egészséggel kapcsolatos témák közül leginkább a testmozgással kapcsolatos információk iránt érdeklődtek (közel felük), a többi témakör (pl.: étkezés, dohányzás, alkoholfogyasztás, drogok, szex) meglehetősen kis hányadukat foglalkoztatta. A keresés gyakorisága az évfolyamok előrehaladtával nőtt. Az információforrások közül leginkább a családjukat tartották hiteles forrásnak, de az idősebb tanulók az internetet és barátaikat is preferálták. ${ }^{6,7}$

Figyelembe véve a Magyarországon eddig iskolások körében végzett országos kutatások eredményeit egyértelmúvé válik, hogy szükség van a fiatalokat megcélzó hatásos, egészségmagatartást fejlesztő prevenciós programokra, ahol a gyerekek megfelelő, hiteles információforrásból tudnak tájékozódni az egészséges életmód témakörében és el tudják sajátítani azokat a készségeket, melyek szükségesek egészségük megtartásához, fejlesztéséhez. Az iskoláskorúak körében szervezett programok egyik lehetséges eleme a kortársoktatás, mely világszerte - így hazánkban is - egyre népszerúbb. Egy friss hazai szakirodalmi áttekintő azonban rámutatott arra, hogy ezek pedagógiai módszeréről és hatékonyságáról nem tudunk még eleget, ami különösen igaz az itthon eddig megvalósult ilyen jellegú kezdeményezések többségére. ${ }^{8}$

Mivel a gyermek életmódjában, egészségmagatartási szokásainak kialakulásában a családi mintán túl az iskola, mint az intézményes szocializáció fontos színtere játszik nagy szerepet ${ }^{9}$, ezért feltételezhető, hogy egy iskolai színtéren végbemenő hatékony egészségfejlesztési program segítségével a magyar iskoláskorúak egészségmagatartása - és így hosszú távon az egészségi állapota - kedvezően befolyásolható. Magyarországon a 20/2012 (VIII/31) EMMI rendelet a nevelési-oktatási intézmények múködéséről és a köznevelési intézmények névhasznála- táról előírja, hogy minden nevelési-oktatási intézményben valósuljon meg a teljes körü egészségfejlesztés, melynek célja, hogy minden gyermek részesüljön az egészségi állapotát hatékonyan fejlesztő, az intézményben rendszerszerűen működő egészségfejlesztő tevékenységekben. ${ }^{10}$ $\mathrm{Az}$ iskolai egészségfejlesztés megvalósítására további útmutatást a Teljes körű Iskolai Egészségfejlesztési Koncepció (TIE Koncepció) ad, mely meghatározza és megalapozza a fejlesztések keretét, a későbbi stratégia, a programok és a beavatkozások koordináltságát.11 A Nemzeti alaptanterv (NAT) pedig lehetőséget biztosít arra, hogy tanrendbe ágyazottan valósuljanak meg az iskolai egészségfejlesztő programok. ${ }^{12}$

Mindezek figyelembe vételével célul tűztük ki egy olyan egészségfejlesztő program kidolgozását középiskolások körében, amelynek hatására a résztvevők bővebb ismerettel rendelkeznek az egészséges életmóddal kapcsolatban és ez a tudás a gyakorlatban, a magatartásuk szintjén is realizálódik. A kutatás első szakasza az alapállapot-felmérés volt, a program során ehhez viszonyítva történik majd meg az eredmények értékelése. Jelen közleményben ezen alapállapot felmérésként elvégzett keresztmetszeti vizsgálat során használt módszert és a kapott eredményeket szeretnénk bemutatni, valamint az erre épülő javaslatokat megfogalmazni.

\section{MÓDSZERTAN}

Kutatásunk kezdetén szakmai-etikai engedélyért folyamodtunk az Egészségügyi Tudományos Tanács Tudományos és Kutatásetikai Bizottsághoz (TUKEB), mely engedélyt a bizottság a vizsgálat megkezdéséhez 2016. október 7-én kiadta (TUKEB ügyiratszám: 49460-5/2016/EKU). Vizsgálatunk helyszínéül egy Hajdú-Bihar megyei középiskolát választottunk, ahol fellelhető mind a három oktatási intézménytípus (gimnázium, szakgimnázium, szakközépiskola). Kutatásunkba a 2016-ban 9. évfolyamot kezdő diákokat vontuk be. Összesen 6 osztály vesz részt a vizsgálatunkban, minden oktatási intézménytípusból 2, ahol egyik osztály az intervenciós, a másik pedig a kontroll csoport részét képzi. A tanulók vizsgálatban való részvételéhez szüleik írásos hozzájárulást adtak, azonban maga a részvétel önkéntes volt, így azt a tanuló visszautasíthatta. 
Az alapállapot-felmérés a 2016/2017-es tanévben történt, egy papír alapú önkitöltős anonim egészségmagatartást mérő kérdőív és egészségismereteket felmérő tudásteszt segítségével. Az egészségmagatartást mérő önkitöltős kérdőívünk alapjául három iskolások körében végzett, hazánkban is lezajlott kutatásban használt kérdőív szolgált: az Iskoláskorú gyermekek egészségmagatartása kutatás (HBSC 2014), az Európai iskolavizsgálat az alkohol- és egyéb drogfogyasztási szokásokról (ESPAD 2015), és az Iskolai Egészségkommunikációs Felmérés (iEKF). 3,5,13

A diákok a kérdőívet a tanév elején töltötték ki egy 45 perces tanórán, a foglalkozások négy témakörével (táplálkozás, testmozgás, függőségek, nemiségszexualitás) összhangban álló tudásteszt kitöltése pedig mindig az adott témakörű foglalkozás előtt történt. A tudástesztet kitöltők elemszáma témakörönként eltért, melynek oka az évközi lemorzsolódás vagy tartós hiányzás volt.

A demográfiai adatokon túl az alábbi témakörökre vonatkozó eredményeket ismertetjük: egészségmagatartási szokások (táplálkozás, fizikai aktivitás), rizikómagatartási szokások (dohányzás, alkoholfogyasztás, szerfogyasztás, szexuális magatartás), egészségi állapot, élettel való elégedettség, valamint az egészségismereteket felmérő teszt eredménye, külön kitérve az egyes témakörökre (táplálkozás, testmozgás, függőségek, nemiségszexualitás).

A táplálkozási szokások témakörében megkérdeztük a tanulókat, hogy hétvégén illetve hétköznap milyen gyakran reggeliznek, valamint, hogy milyen gyakran fogyasztanak zöldséget, gyümölcsöt, édességet, illetve cukros üdítőitalt.

Fizikai aktivitásuk kapcsán felmértük, hogy a kérdőív kitöltését megelőző héten hány olyan nap volt, amikor legalább 60 perces testmozgást végeztek mérsékelt intenzitással vagy intenzív módon. Ezt a HBSC vizsgálati protokoll alapján, az alábbi módon értékeltük: elegendő a testmozgás, ha a hét minden napján mozgott a gyermek, közel elegendő, ha 5-6 napon, kevés, ha 3-4 napon és nagyon kevés, ha kevesebb, mint 2 napon végzett legalább 60 percnyi testmozgást. ${ }^{3,14}$

Megkérdeztük, hogy a tanulók egy átlagos hétköznap illetve hétvégi napon mennyi időt fordítanak valamilyen képernyő előtti tevékenységre, ezen belül televízió és video nézésre, számítógépen, és egyéb elektronikus eszközön (játékkonzol, táblagép, okostelefon) történő játékra, illetve számítógép (okostelefon, táblagép) használatára játékon kívül. Szintén a HBSC felmérés módszertana alapján a legalább napi 2 óra használatot tekintettük soknak. ${ }^{3,14}$ Rizikómagatartás témakörén belül a dohányzás, elektronikus cigarettázás, és vízipipázás életprevalenciáját és e tevékenységek rendszerességét, az alkoholfogyasztás és a lerészegedés életprevalenciáját, az illegális szerfogyasztást, és a szexuális élet megkezdését vizsgáltuk. ${ }^{3,14}$

Megkérdeztük, hogy a diákoknak van-e valamilyen tartós betegsége, milyennek gondolják az egészségüket, illetve a 0-10 fokozatú Cantril létra segítségével képet kaptunk arról is, hogy mennyire elégedettek életükkel. ${ }^{3}$

Az egészséges életmóddal kapcsolatos tudásteszt feladatai feleletválasztós (zárt) kérdések voltak (alternatív feladatok, páros asszociáció, választásos feladatok, hiba kutatás, többszörös választás), melyek négy témakört dolgoztak fel: táplálkozás, testmozgás, függőségek, nemiség-szexualitás. A diákok által elért átlagpontszámokat összességében és témakörökre bontva is kiszámoltuk.

A kérdőív és a tesztek kitöltésénél népegészségügyi szakember vett részt, mint felügyelő, így ha a tanulóknak kérdése akadt, szakszerű tájékoztatásban részesültek. Az esetleges beviteli hibák elkerülése végett kettős adatrögzítés történt, az adatok tisztítása során pedig a kérdőív kérdéseinek logikai összefüggéseit vettük figyelembe.

Az adatelemzéshez a STATA 10.1 programot használtuk. Az intézménytípusonkénti összevetéshez khi-négyzet próbát, Fisher-egzakt tesztet, ANOVA-t, illetve a nem normál eloszlású folytonos változók esetén Kruskal-Wallis tesztet alkalmaztunk.

\section{EREDMÉNYEK}

A felmérésben 130 tanuló vett részt, a részvételi arány $87,3 \%$ volt. A diákok nemi és oktatási intézménytípusonkénti megoszlását az 1 . táblázat mutatja.

A tanulók 38,3\%-a reggelizett minden hétköznap, gyümölcsöt 16,4\%-uk, zöldséget 11,7\%-uk, édességet és üdítőitalt pedig közel harmaduk fogyasztott napi rendszerességgel. A szakközépiskolába járók több édességet $(p=0,034)$ és üdítőitalt $(p=0,001)$ fogyasztottak, mint a gimnázium és szakgimnázium tanulói. [2. táblázat] 
1. táblázat: Demográfiai adatok

\begin{tabular}{|c|c|}
\hline & $\% \quad(n)$ \\
\hline \multicolumn{2}{|l|}{ Nemek aránya } \\
\hline fiú & $47,7 \%(62)$ \\
\hline lány & $52,3 \%(68)$ \\
\hline \multicolumn{2}{|c|}{ Oktatási intézménytípusok közötti megoszlás } \\
\hline Gimnázium & $33,9 \%(44)$ \\
\hline Szakgimnázium & $36,9 \%(48)$ \\
\hline Szakközépiskola & $29,2 \%(38)$ \\
\hline
\end{tabular}

Forrás: saját szerkesztés

2. táblázat: A tanulók táplálkozási szokásai oktatási intézménytípus szerinti bontásban

\begin{tabular}{|c|c|c|c|c|c|}
\hline & $\begin{array}{c}\text { Teljes évfolyam } \\
\%(n)\end{array}$ & $\begin{array}{l}\text { Gimnázium } \\
\%(n)\end{array}$ & $\begin{array}{l}\text { Szakgimnázium } \\
\%(n)\end{array}$ & $\begin{array}{c}\text { Szakközépiskola } \\
\%(n)\end{array}$ & p-érték \\
\hline $\begin{array}{l}\text { Reggelizés minden } \\
\text { hétköznap ( } n=128)\end{array}$ & $38,3 \%(49)$ & $36,4 \%(16)$ & $38,3 \%(18)$ & $40,5 \%(15)$ & 0,928 \\
\hline $\begin{array}{l}\text { Reggelizés hétvégén mind- } \\
\text { két nap }(n=125)\end{array}$ & $72,0 \%(90)$ & $68,2 \%(30)$ & $72,3 \%(34)$ & $76,5 \%(26)$ & 0,720 \\
\hline $\begin{array}{l}\text { Gyümölcsfogyasztás } \\
\text { naponta }(n=128)\end{array}$ & $16,4 \%(21)$ & $15,9 \%(7)$ & $19,2 \%(9)$ & $13,5 \%(5)$ & 0,782 \\
\hline $\begin{array}{l}\text { Zöldségfogyasztás } \\
\text { naponta }(n=128)\end{array}$ & $11,7 \%(15)$ & $9,1 \%(4)$ & $6,3 \%(3)$ & $21,6 \%(8)$ & 0,078 \\
\hline $\begin{array}{l}\text { Édességfogyasztás } \\
\text { naponta }(n=129)\end{array}$ & $31,0 \%(40)$ & $25,0 \%(11)$ & $23,4 \%(11)$ & $47,4 \%(18)$ & 0,034 \\
\hline $\begin{array}{l}\text { Cukros üdítőital } \\
\text { fogyasztás naponta }(n=128)\end{array}$ & $32,8 \%(42)$ & $14,0 \%(6)$ & $33,3 \%(16)$ & $54,1 \%(20)$ & 0,001 \\
\hline
\end{tabular}

Forrás: saját szerkesztés

1. ábra: Kérdőiv kitöltése előtti héten, legalább mérsékelt intenzitással végzett testmozgás gyakorisága nemenként



Forrás: saját szerkesztés 
A kérdőív kitöltését megelőző héten a tanulók ( $n=125$ ) 31,2\%-a nagyon kevés, 26,4\%-a kevés, 25,6\%-a közel elegendő, és 16,8\%-uk elegendő testmozgást végzett, tehát mind a 7 napon legalább
60 percet mozgott minimum mérsékelt intenzitással. A legtöbb testmozgást a szakgimnazisták végezték, majd a gimnazisták, és a szakközépiskola tanulói a legkevesebbet $(p=0,001)$. [1. ábra]

3. táblázat: Naponta legalább 2 órát képernyő elött töltők aránya tevékenység és oktatási intézménytípus szerinti bontásban

\begin{tabular}{|c|c|c|c|c|c|c|c|}
\hline & & $\begin{array}{l}\text { Teljes } \\
\text { minta }\end{array}$ & p-érték & $\begin{array}{l}\text { Gimnázium } \\
\%(n)\end{array}$ & $\begin{array}{c}\text { Szakgimnázium } \\
\%(n)\end{array}$ & $\begin{array}{c}\text { Szakközépiskola } \\
\% \text { (n) }\end{array}$ & p-érték \\
\hline \multirow{2}{*}{$\begin{array}{l}\text { TV, video } \\
\text { nézés }\end{array}$} & $\begin{array}{l}\text { Hétköznap } \\
(\mathrm{n}=130)\end{array}$ & $64,6 \%$ & \multirow{2}{*}{$<0,001$} & $61,4 \%(27)$ & $64,6 \%(31)$ & $68,4 \%(26)$ & 0,801 \\
\hline & $\begin{array}{l}\text { Hétvégén } \\
(n=130)\end{array}$ & $90,8 \%$ & & $81,8 \%(36)$ & $95,8 \%(46)$ & $94,7 \%(36)$ & 0,059 \\
\hline \multirow{2}{*}{$\begin{array}{l}\text { Elektronikus } \\
\text { eszköz hasz- } \\
\text { nálata }\end{array}$} & $\begin{array}{l}\text { Hétköznap } \\
(n=129)\end{array}$ & $52,7 \%$ & \multirow{2}{*}{$<0,001$} & $43,2 \%(19)$ & $58,3 \%(28)$ & $56,8 \%(21)$ & 0,293 \\
\hline & $\begin{array}{l}\text { Hétvégén } \\
(n=129)\end{array}$ & $76,7 \%$ & & $63,6 \%(28)$ & $89,6 \%(43)$ & $75,7 \%(28)$ & 0,013 \\
\hline \multirow{2}{*}{$\begin{array}{l}\text { Játék elek- } \\
\text { tronikus esz- } \\
\text { közön }\end{array}$} & $\begin{array}{l}\text { Hétköznap } \\
(n=130)\end{array}$ & $44,6 \%$ & \multirow{2}{*}{$<0,001$} & $52,3 \%(23)$ & $31,3 \%(15)$ & $52,6 \%(20)$ & 0,064 \\
\hline & $\begin{array}{l}\text { Hétvégén } \\
(\mathrm{n}=127)\end{array}$ & $68,5 \%$ & & $65,9 \%(29)$ & $68,1 \%(32)$ & $72,2 \%(26)$ & 0,830 \\
\hline
\end{tabular}

Forrás: saját szerkesztés

4. táblázat: Rizikómagatartási formák prevalenciája oktatási intézménytípus szerinti bontásban

\begin{tabular}{|c|c|c|c|c|c|c|}
\hline & & $\begin{array}{l}\text { Teljes évfo- } \\
\text { lyam } \\
\%(n)\end{array}$ & $\begin{array}{l}\text { Gimnázium } \\
\% \text { (n) }\end{array}$ & $\begin{array}{c}\text { Szakgimnázium } \\
\%(n)\end{array}$ & $\begin{array}{c}\text { Szakközépiskola } \\
\%(n)\end{array}$ & p-érték \\
\hline & & & Dohányz & & & \\
\hline & $\begin{array}{l}\text { Életprevalencia } \\
(n=126)\end{array}$ & $46,8 \%(59)$ & $37,2 \%(16)$ & $50,0 \%(23)$ & $54,1 \%(20)$ & 0,278 \\
\hline Cigaretta & $\begin{array}{l}\text { Legalább hetente } \\
\text { egyszer él vele } \\
(n=128)\end{array}$ & $21,9 \%(28)$ & $2,3 \%(1)$ & $27,1 \%(13)$ & $37,8 \%(14)$ & $<0,001$ \\
\hline & $\begin{array}{l}\text { Életprevalencia } \\
(n=123)\end{array}$ & $29,3 \%(36)$ & $16,3 \%(7)$ & $33,3(16)$ & $40,6 \%(13)$ & 0,053 \\
\hline $\begin{array}{l}\text { E-clga- } \\
\text { retta }\end{array}$ & $\begin{array}{l}\text { Legalább hetente } \\
\text { egyszer él vele } \\
(n=130)\end{array}$ & $6,2 \%(8)$ & $4,6 \%(2)$ & $4,2 \%(2)$ & $10,5 \%(4)$ & 0,477 \\
\hline & $\begin{array}{l}\text { Életprevalencia } \\
(n=125)\end{array}$ & $39,2 \%(49)$ & $39,5 \%(17)$ & $41,3 \%(19)$ & $36,1 \%(13)$ & 0,891 \\
\hline Vízipipa & $\begin{array}{l}\text { Legalább hetente } \\
\text { egyszer él vele } \\
(n=130)\end{array}$ & $7,7 \%(10)$ & $6,8 \%(3)$ & $8,3 \%(4)$ & $7,9 \%(3)$ & 0,999 \\
\hline & & & Alkoholfogy & & & \\
\hline $\begin{array}{l}\text { Alkoholfo } \\
\text { ciája }(n=1\end{array}$ & sztás életprevalen- & $88,4 \%$ (107) & $88,1 \%(37)$ & $86,4 \%(38)$ & $91,4 \%(32)$ & 0,829 \\
\hline $\begin{array}{l}\text { Részegség } \\
(n=124)\end{array}$ & etprevalenciája & $54,8 \%(68)$ & $35,7 \%(15)$ & $63,0 \%(29)$ & $66,7 \%(24)$ & 0,009 \\
\hline
\end{tabular}

Forrás: saját szerkesztés 
Általánosságban elmondható, hogy a tanulók hétvégenként több időt töltöttek képernyő előtt, mint hétköznapokon $(p<0,001)$. A hétvégi számítógép és más elektronikus eszköz használatánál szignifikáns különbséget találtunk a különböző intézménytípusban tanulók között, eszerint a gimnazisták töltöttek kevesebb időt ezen eszközök használatával, míg a szakgimnazisták a legtöbbet $(p=0,013)$. [3. táblázat] A tanulók közel fele kipróbálta már a dohányzást, harmaduk az elektronikus-cigarettát, és 39\%-uk a vízipipát. A rendszeres használatot illetően elmondhatjuk, hogy a gimnazisták közül szignifikánsan kevesebben voltak, akik legalább heti rendszerességgel rágyújtottak a cigarettára, mint más intézménytípusban tanuló társaik $(p<0,001)$. [4. táblázat] A legtöbb tanuló fogyasztott már alkoholt, és több, mint felük került már részeg állapotba élete során. A szakgimnazisták és a szakközépiskolások részegségének életprevalen- ciája szignifikánsan magasabb, mint a gimnazistáké $(p=0,009)$. [4. táblázat] Az évfolyamból összesen 4 tanuló élt már illegális szerrel, mindegyikük kipróbálta a marihuánát, de volt aki közülük más szereket is.

A válaszadó tanulók ( $n=123$ ) 26,8\%-ának volt már szexuális kapcsolata, legtöbbjüknek először 14-15 éves korban. Ezen tanulók 81,8\%-a óvszerrel, 15,2\%-a tablettával, 6,1\%-a egyéb módon, 15,2\%-a pedig semmivel sem védekezett a legutóbbi szexuális együttlétük alkalmával. A különböző oktatási intézménytípusok között a védekezés módját tekintve szignifikáns különbséget nem találtunk, viszont az elmondható, hogy a gimnazisták közül szignifikánsan kevesebben éltek szexuális életet, mint szakgimnáziumi, vagy szakközépiskolai társaik $(p=0,001)$. [2. ábra]

\section{2. ábra: Szexuális kapcsolatot már létesített tanulók aránya oktatási intézménytípus szerint ( $n=33)$}

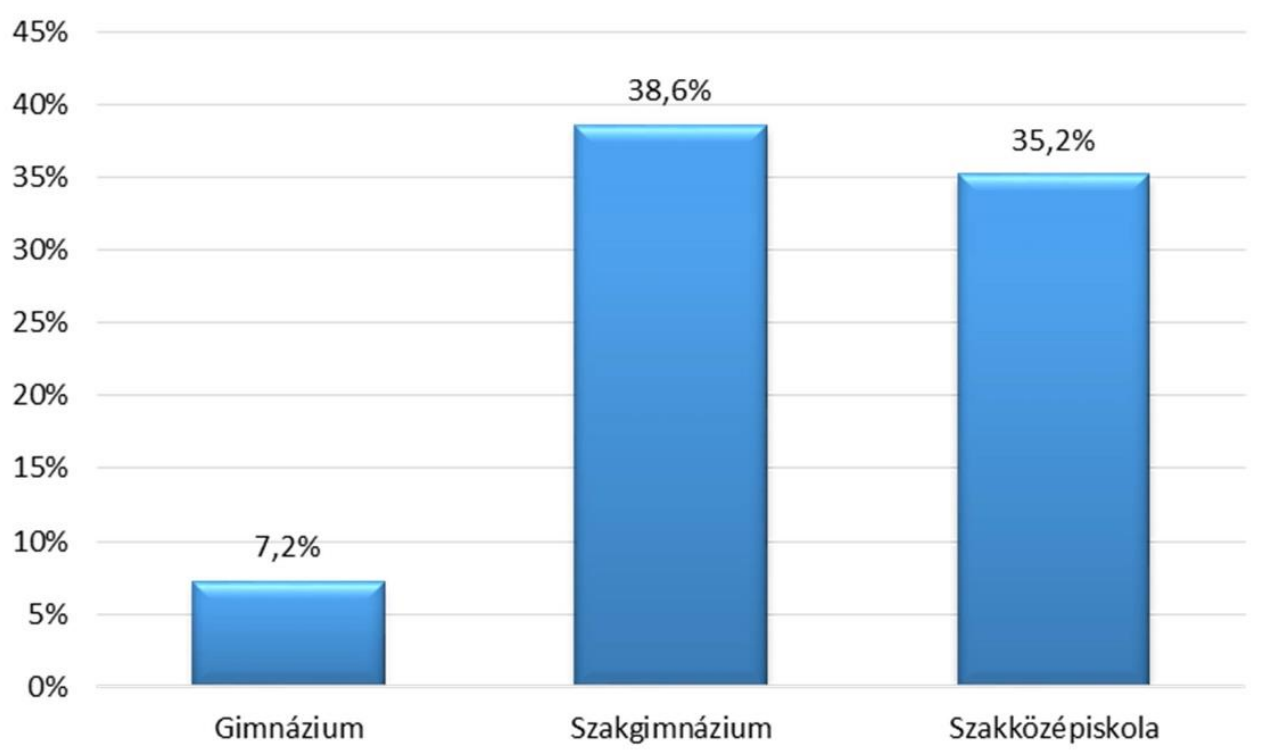

Forrás: saját szerkesztés

A válaszadók 13\%-ának van valamilyen tartós betegsége, ehhez képest azonban a tanulók csupán 42\%a vélte jónak, vagy kitűnőnek egészségi állapotát. Az élettel való elégedettséget mérő 0-10-ig terjedő skálán a tanulók átlagpontszáma 7,01 (SD=1,93; min.: 0, max.: 10) volt. A szakközépiskolába járó tanulók élettel való elégedettsége szignifikánsan alacsonyabb volt, mint más intézménytípusba járó társaiké $(p=0,002)$. [5. táblázat]
A tanulók az egészséges életmóddal kapcsolatos tudásteszten elérhető 96 pontból átlagosan 51,8 pontot értek el ( $S D=10,32$; min: 28, max: 73). Összességében elmondható, hogy a teszten és a részteszteken a gimnazisták szerezték meg a legmagasabb pontszámot, majd a szakgimnazisták és - a szexualitással kapcsolatos teszten kívül - végül a szakközépiskolások következtek. [6. táblázat] 
5. táblázat: A tanulók egészségi állapota, élettel való elégedettsége oktatási intézménytípus szerint

\begin{tabular}{|c|c|c|c|c|c|}
\hline & $\begin{array}{l}\text { Teljes évfolyam } \\
\text { (n) }\end{array}$ & $\begin{array}{l}\text { Gimnázium } \\
\text { (n) }\end{array}$ & $\begin{array}{l}\text { Szakgimnázium } \\
\text { (n) }\end{array}$ & $\begin{array}{c}\text { Szakközépiskola } \\
\text { (n) }\end{array}$ & p-érték \\
\hline Tartós beteg ( $n=127)$ & $13,3 \%(17)$ & $16,3 \%(7)$ & $14,6 \%(7)$ & $8,1 \%(3)$ & 0,575 \\
\hline \multicolumn{6}{|c|}{ Szubjektív egészség ( $n=127)$} \\
\hline Rossz/nagyon rossz & $16,3 \%(21)$ & $15,9 \%(7)$ & $12,8 \%(6)$ & $21,1 \%(8)$ & \multirow{3}{*}{0,820} \\
\hline Megfelelő & $41,9 \%(54)$ & $45,5 \%(20)$ & $40,4 \%(19)$ & $39,5 \%(15)$ & \\
\hline Jó/kitűnő & $41,9 \%(54)$ & $38,6 \%(17)$ & $46,8 \%(22)$ & $39,5 \%(15)$ & \\
\hline \multicolumn{6}{|c|}{ Élettel való elégedettség ( $n=128$ ) } \\
\hline $\begin{array}{l}\text { Cantril létra átlag } \\
\text { pontszám } \\
\text { (0-10 pont) }\end{array}$ & $\begin{array}{c}7,01 \\
(S D=1,93 \\
\min .: 0 \\
\max .: 10)\end{array}$ & $\begin{array}{c}7,11 \\
(S D=1,59, \min .: 4 \\
\max .: 10)\end{array}$ & $\begin{array}{c}7,49 \\
(S D=1,54, \min .: 4 \\
\max .: 10)\end{array}$ & $\begin{array}{c}6,27 \\
(S D=2,49, \min .: 0 \\
\max .: 10)\end{array}$ & 0,002 \\
\hline
\end{tabular}

Forrás: saját szerkesztés

6. táblázat: A tanulók egészséges életmóddal kapcsolatos tudásteszten elért átlagpontszámai témák és oktatási intézménytípus szerinti bontásban

\begin{tabular}{|c|c|c|c|c|c|}
\hline & Teljes évfolyam & Gimnázium & Szakgimnázium & Szakközép & p-érték \\
\hline $\begin{array}{l}\text { Összesen elért } \\
\text { pontszám (max. } \\
96 \text { pont) ( } n=109)\end{array}$ & $\begin{array}{c}51,8(S D=10,3 \\
\min .: 23, \max .: 73)\end{array}$ & $\begin{array}{c}58,3(\mathrm{SD}=6,6 \\
\min .: 42, \max .: 73)\end{array}$ & $\begin{array}{c}48,5(S D=10,6 \\
\min .: 23, \max .: 67)\end{array}$ & $\begin{array}{c}47,1(\mathrm{SD}=9,9 \\
\min .: 29, \max .: 73)\end{array}$ & $<0,001$ \\
\hline $\begin{array}{l}\text { Táplálkozás teszt } \\
\text { (max. } 36 \text { pont) } \\
(\mathrm{n}=130)\end{array}$ & $\begin{array}{l}15,2(S D=15,2 \\
\min .: 5, \max .: 25)\end{array}$ & $\begin{array}{c}16,9(S D=3,4, \min .: 9 \\
\max .: 23)\end{array}$ & $\begin{array}{c}\text { 14,6 }(S D=3,9, \min .: 7 \\
\max .: 23)\end{array}$ & $\begin{array}{c}13,9(S D=4,6, \min .: 5 \\
\max .: 25)\end{array}$ & 0,001 \\
\hline $\begin{array}{l}\text { Fizikai aktivitás } \\
\text { teszt (max. } 20 \\
\text { pont) }(n=120)\end{array}$ & $\begin{array}{c}14,7(S D=3,3 \\
\min .: 5, \max .: 20)\end{array}$ & $\begin{array}{c}16,1(S D=2,9, \min .: 5 \\
\max .: 20)\end{array}$ & $\begin{array}{c}14,2(S D=3,4, \min .: 7 \\
\max .: 20)\end{array}$ & $\begin{array}{c}\text { 13,3 }(\mathrm{SD}=3,1, \min .: 5 \\
\max .: 19)\end{array}$ & $<0,001$ \\
\hline $\begin{array}{l}\text { Függőség teszt } \\
\text { (max. } 19 \text { pont) } \\
(n=117)\end{array}$ & $\begin{array}{c}\text { 10,7 (SD=3,3, } \\
\min .: 0, \text { max.: } 17)\end{array}$ & $\begin{array}{c}11,7(S D=2,4, \min .: 6 \\
\text { max.:17) }\end{array}$ & $\begin{array}{c}10,9(S D=4,0, \min .: 0 \\
\text { max.:17) }\end{array}$ & $\begin{array}{c}9,3(S D=3,6, \min .: 3 \\
\max .: 16)\end{array}$ & 0,002 \\
\hline $\begin{array}{l}\text { Nemiség, szexua- } \\
\text { litás teszt (max. } \\
26 \text { pont) ( } n=116)\end{array}$ & $\begin{array}{c}10,8(S D=4,1 \\
\min .: 0, \text { max.: } 20\end{array}$ & $\begin{array}{c}13,3(S D=3,4, \min .: 4 \\
\max .: 20)\end{array}$ & $\begin{array}{c}8,9(S D=3,8, \min .: 0 \\
\max .: 16)\end{array}$ & $\begin{array}{c}10,0(S D=3,7, \min .: 4 \\
\max .: 19)\end{array}$ & $<0,001$ \\
\hline
\end{tabular}

Forrás: saját szerkesztés

\section{MEGBESZÉLÉS}

Az alapállapot-felmérés eredményei alapján elmondható, hogy a vizsgálatba bevont tanulók táplálkozási szokásai nem voltak kielégítőek, közülük is a szakközépiskolába járók mutattak kedvezőt- lenebb képet az édesség- és cukros üdítőital fogyasztás tekintetében. A diákok közül kevesen végeztek elegendő testmozgást, a szakközépiskolások mozogtak a legkevesebbet. Képernyő előtt passzívan igen sokan töltöttek naponta több, mint 2 órát. A hétvégén a tanulók minden esetben több 
időt töltöttek TV vagy videó nézéssel, számítógép, vagy más elektronikus eszköz használatával, illetve ezen eszközökkel való játszással. Elmondható az is, hogy ezen időszakban a szakgimnazisták és szakközépiskolások szánták a legtöbb időt számítógépezésre, elektronikus eszköz használatra.

A rizikómagatartást tekintve a tanulók közel fele próbálta már a cigarettát, és a rendszeresen dohányzók a tanulók egyötödét tették ki. Az elektronikus cigarettát, vagy vízipipát már ennél kevesebben próbálták ki, illetve használták rendszeresen. Közel 90\%-uk ivott már valamilyen szeszes italt, és 54,8\%-uk volt már részeg életében legalább egyszer. Negyedüknek volt már szexuális kapcsolata. A szakgimnazista és szakközépiskolás diákok között szignifikánsan magasabb volt a rendszeresen dohányzók aránya, a részegség életprevalenciája, valamint a szexuális életet megkezdők aránya a gimnáziumban tanuló társaikhoz képest.

Az oktatási intézménytípusok közötti különbségeket nézve elmondható, hogy a kapott rizikómagatartásra vonatkozó eredményeink összhangban vannak a hazai HBSC 2014 felmérés eredményeivel: az érettségit nem adó oktatási intézménytípusban tanulók kedvezőtlenebb képet mutattak a dohányzás, a részegség és a szexuális élet megkezdését illetően. $^{3}$

Vizsgálatunkban a válaszadók kis hányada rendelkezett valamilyen tartós betegséggel, ehhez képest a tanulók alig több, mint 40\%-a vélte jónak, vagy kitúnőnek egészségi állapotát. A tanulók életükkel átlagosan elégedettek, de a szakközépiskolába járó tanulók kevésbé, mint más intézménytípusba járó társaik.

A tudásteszten elért eredményeket tekintve látható, hogy vannak alapvető tudásbeli hiányosságok, amelyek kiküszöbölése nélkül nehezen lehet tudatos, egészséges életmódot folytatni. Különböző oktatási intézménytípusban tanulók tudásszintje eltérést mutatott: a szakközépiskolás tanulók egészséges életmóddal kapcsolatos tudása alacsonyabb volt. Ezen tudásbeli különbség közrejátszhat abban, hogy a szakközépiskolások egészségmagatartása alakult a legtöbb mutató esetében a legkedvezőtlenebbül.

Vizsgálatunk limitációjaként elmondható, hogy több akadályba is ütköztünk a gyakorlati megvalósítás során, mely a kezdeti állapotfelmérést valamilyen szinten korlátozta. Az egyik ilyen tényező a szülők és a gyerekek együttműködési hajlandóságának hiánya volt a vizsgálatban való részvételt illetően, mely akadályozta vizsgálatunk gördülékenységét és ezért már a kutatás kezdetén egy egész osztályt ki kellett zárnunk. Maga az adatfelvétel a tanulók hiányzása miatt hosszadalmasabb volt, mint terveztük, hiszen a hiányzó tanulókkal a kérdőív kitöltését be kellett pótoltatni annak érdekében, hogy az alapállapotfelmérés eredményei mindenkiről rendelkezésre álljanak.

A tanulókat vizsgálatunkban anonim módon nyomon követjük, melynek módszere (egyéni kód és ellenőrző kérdések alkalmazása) újszerű megoldásnak mondható, és egyúttal megteremti a lehetőségét az eredmények egyéni - és nem csak csoportszintű (intervenciós vs. kontroll osztály) - értékelésének. A papír alapú tesztek rögzítése a kérdőív terjedelme miatt időigényes folyamat, ezért a továbbiakban tervezzük az online kitöltési módra történő áttérést.

\section{KÖVETKEZTETÉSEK}

A jelen közleményben bemutatott alapállapotfelmérés eredményeit az intervenció kidolgozásához és az azok által elért eredmények értékeléséhez használjuk majd fel, mégpedig úgy, hogy a tervezés során a kiugróan kedvezőtlen egészségmagatartásbeli problémákat ( $p l .:$ egészségtelen táplálkozás, mozgásszegény életmód, problémás alkoholfogyasztás) priorizáljuk és az ebben az iskolában kevésbé jellemző területek (pl. illegális szerfogyasztás) tárgyalását későbbre tervezzük. Mivel a foglalkozásoknak idomulniuk kell a serdülók alaptudásához, azok tervezésénél ezt fontos figyelembe vennünk, pl. a szakgimnáziumban és szakközépiskolában a hiányosabb biológiai ismereteket be kell pótolni, egy-egy témakörre több időt kell szánni.

Az iskolai intervenció kidolgozása során azt is szem előtt kell tartani, hogy ez csak egy kis szelete a sikeres egészségfejlesztésnek, hiszen az egészséges életmód elsajátításához más, iskolán kívüli tényezők is hozzájárulnak. A legközvetlenebb életmódot befolyásoló tényező a tanuló családi mintája és családjának szocioökonómiai helyzete. ${ }^{15}$ Ebből fakadóan a tanulókat megcélzó intervenciós programok sikerességének érdekében célszerű a gyermekek egészségnevelésében fontos szerepet betöltő pedagógusok és szülők bevonása is. Az Egészségügyi Tudományos Tanács állásfoglalása szerint a 
gyermekek egészségnevelése során e két szereplő (szülők, pedagógusok) együttműködése elengedhetetlen. ${ }^{16}$ Ugyanakkor arról sem feledkezhetünk meg, hogy az egészségfejlesztésben élenjáró más országok az iskolai egészségfejlesztést a helyi közösségbe ágyazva, több társadalmi szereplő bevonásával és több beavatkozási irányból valósítják meg. ${ }^{17}$ A vizsgálatunkra épülő intervenciós program módszertanát, a megvalósítás során szerzett gyakorlati tapasztalatokat és az elért eredményeket további közleményekben szeretnénk majd bemutatni.

\section{HIVATKOZÁSOK}

\section{KÖSZÖNETNYILVÁNITTÁS}

A közölt munka az EU és az Európai Szociális Alap által támogatott EFOP-3.6.3-VEKOP-16-2017-00009 projekt keretében valósult meg. Ezúton szeretnénk megragadni az alkalmat, és megköszönni a résztvevő középiskola vezetőségének kutatásunk befogadását, az együttműködő tanárok készséges segítségét, és nem utolsó sorban a résztvevő tanulók közreműködését, és szüleik ehhez való hozzájárulását.

\footnotetext{
${ }^{1}$ Varsányi P., Vitrai J., et al. Egészségjelentés 2016, Nemzeti Egészségfejlesztési Intézet, Budapest, 2017. január

2 Inchley J et al. eds. Growing up unequal: gender and socioeconomic differences in young people's health and wellbeing. Health Behaviour in School-aged Children (HBSC) study: International report from the 2013/2014 survey. ${ }^{3}$ Németh Á., Költő A. (Szerk.): Az Iskoláskorú gyermekek egészségmagatartása elnevezésű, az Egészségügyi Világszervezettel együttműködésben megvalósuló nemzetközi kutatás 2014. évi felméréséről készült nemzeti jelentés, Budapest,
} Nemzeti Egészségfejlesztési Intézet 2016.

${ }^{4}$ ESPAD Group (2016), ESPAD Report 2015: Results from the European School Survey Project on Alcohol and Other Drugs, Publications Office of the European Union, Luxembourg.

${ }^{5}$ Elekes Zs. (Szerk.), Európai iskolavizsgálat az alkohol- és egyéb drogfogyasztási szokásokról - 2015 Magyarországi eredmények, Budapesti Corvinus Egyetem Társadalomtudományi és Nemzetközi Kapcsolatok Kar Szociológia és Társadalompolitika Intézet, Budapest, 2016

${ }^{6}$ Kutatási terv (2014): Iskolai Egészségkommunikációs Felmérés (iEKF), TÁMOP-6.1.3.B.2013-0001 Népegészségügyi kommunikáció fejlesztése http://www.egeszseg.hu/szakmai oldalak/assets/cikkek/16-05/iskolaiekf-kutatasiterv.pdf (Elérve: 2018.04.30.)

7 Zsíros E., Balku E., Vitrai J. Egészségkommunikációs Felmérés Eredményei II. - Iskolai felmérés, Egészségfejlesztés, LVII. évfolyam, 2016.03.szám; doi: 10.24365/ef.v57i3.45

${ }^{8}$ Lukács-Jakab Á. et al. Kortárs egészségfejlesztési programok gyermekek és fiatalok körében a hazai és a nemzetközi szakirodalom tükrében - Szisztematikus áttekintés, Egészségfejlesztés LIX. évfolyam 2018. 1. szám doi: 10.24365/ef.v59i1.215

${ }^{9}$ Egészségfejlesztés az iskolákban (tanulmány) Akkreditált tanárképzési programmal párosuló, komplex iskolai egészségfejlesztési tananyagok áttekintése, OEFI. http://regi.oefi.hu/ipb.pdf (Elérve 2018.04.20.)

10 20/2012. (VIII. 31.) EMMI rendelet a nevelési-oktatási intézmények működéséről és a köznevelési intézmények névhasználatáról https://net.jogtar.hu/jogszabaly?docid=a1200020.emm (Elérve: 2018.04.22)

${ }^{11}$ Teljes körű Egészségfejlesztési Koncepció, Nemzeti Egészségfejlesztési Intézet, 2015. http://projektek.egeszseg.hu/documents/17618/2222750/Teljes+k\%C3\%B6r\%C5\%B1+lskolai+Eg\%C3\%A9szs\%C3\%A9gfejleszt\%C3\%A9s+Koncepci\%C3\%B3.pdf/9bd631f4-b027-4802-8cec-3e343f29c5fe?version=1.0 (Elérve: 2018.04.22.)

12 10/2012. (VI. 4.) Korm. rendelet A Nemzeti alaptanterv kiadásáról, bevezetéséról és alkalmazásáról Magyar Közlöny 66. szám, 2012. június 4. http://ofi.hu/sites/default/files/attachments/mk nat 20121.pdf (Elérve: 2018.05.03)

${ }^{13}$ Kérdőív (2014): Iskolai Egészségkommunikációs felmérés (iEKF) a TÁMOP-6.1.3.B-12/1-2013-0001 „Népegészségügyi kommunikáció fejlesztése"program keretében http://www.egeszseg.hu/szakmai oldalak/assets/cikkek/16-05/ekf-iskolai-9osztaly-kerdoiv.pdf (Elérve: 2018.05.03.)

${ }^{14}$ World Health Organization Physical activity Fact sheet Updated 23 February 2018 http://www.who.int/mediacentre/factsheets/fs385/en/ (Elérve: 2018.04.22.)

${ }_{15}$ Margaret D. H., Edith C., Socioeconomic Status and Health Behaviors in Adolescence: A Review of the Literature, Journal of Behavioral Medicine, June 2007, 30:263

${ }^{16}$ Egészségügyi Tudományos Tanács, Az ETT Elnökség állásfoglalása az egészségnevelés fejlesztéséről, 65658/2017/ETT https://ett.aeek.hu/wp-content/uploads/2018/01/egeszsegneveles 201712.pdf (Elérve: 2018.05.03.)

17 Járomi É., Vitrai J. Az iskolai egészségfejlesztés hazai és nemzetközi szemléleteinek bemutatása. Egészségfejlesztés, LVIII. évfolyam, 2017. 1. szám doi: 10.24365/ef.v58i1.145 